\title{
GAMBUT LESTARI: AWARENESS SOLUTIONS FOR THE CRISIS OF PEATLAND
}

\author{
${ }^{1}$ Fauzan Ishaq, ${ }^{2}$ Rani Melani Aldina Wijaya, ${ }^{3}$ Alya Lihan Eltofani \\ ${ }^{123}$ Business Administration, Institut Teknologi Bandung, Bandung, Indonesia \\ ${ }^{1}$ Fauzan_ishaq@sbm-itb.ac.id, 2Ranimelani_aldinawijaya@sbm- \\ itb.ac.id, ${ }^{3}$ Alyalihan_eltofani@sbm-itb.ac.id
}

\begin{abstract}
Peatland reserves one-third of the world's carbon storage. In 1 year, it is evaluated that the peatland absorbs and contains 22.5 - 43.5 gigatonnes of carbon, which is proportionate to the outflows of 17-33 billion cars. Looking back on 2015, more than $50 \%$ or 2 million hectares of peatlands were burned down, causing 220 trillion rupiah loss, victims suffering from respiratory diseases, disconnection of transportation networks, and threats to biodiversity. The aim of this paper is to know the strategies used to increase awareness of peatlands, and these discoveries are appearing the sort of data and information that required prioritization to educate and advance such awareness. The method used for this paper is divided into two for the project planning and data collection instrument. For the data collection instrument, we used data from third parties. The project planning that we conclude are including gambutlestari.com, pilot, share information, training \& education, signing the petition, and donation. Our project planning is encouraging the participation of people to increase the preventive action towards peatlands damage and indirectly fixed the peatlands damage that previously happened. In conclusion, it is a developed system to create a discussion for an educational training program. Hence, each party can embrace communicating and advancing awareness of the peatland issue. Achieving our goal to be able to increase awareness of peatlands in Indonesia, we provide a one-stop service called "Push-Sustainable Peatlands," which can be accessed easily by everyone.
\end{abstract}

Keywords: Push-Gambut Lestari, Peatland, Awareness, Communication, Pilot Project

DOI: $10.33541 /$ sp.v21i2.2254

Sociae Polites : Majalah IImiah Sosial Politik

Faculty of Social and Political Science, Universitas Kristen Indonesia

ISSN 1410-3745 print/ ISSN 2620-4975 online

Volume 21, Number 2 (Youth Peatland Conference)

Pages 245-258 


\section{Introduction}

Based on information from Forest Watch Indonesia, the peatland zone in Indonesia is around 19.3 million ha or more than $10 \%$ of the entire land range. The spread of peatlands within the region of Indonesia is scattered and more broadly spread on the islands of Sumatra, Papua, and Kalimantan. For the Sumatra island, the biggest peatland is found in Riau, which covers an area of 4 million ha. Forest Watch Indonesia observed that in 2009, the range of peatland with timberland cover was around 10.1 million HA, whereas in 2013, as it were 9 million HA was still covered by normal forest. Among all the ranges, the biggest peatland in Indonesia is peatland that is covered with timberland, about 450 hectares, in Riau, West Kalimantan, Papua, and Central Kalimantan.

The role of peatland is very important in controlling the impact of climate change in Indonesia. Peatland stores one-third of the world's carbon reserves. In 1 year, it is evaluated that the peatland absorbs and contains 22.5 - 43.5 gigatonnes of carbon, which is proportionate to the outflows of 17-33 billion cars (FWI, 2017). Many changes in the function of peatlands have been caused by the development of industrial plantations to oil palm and cases of illegal logging. Back in 2015, more than 50\% or 2 million hectares of forest were burned down. This incident resulted in the loss of 220 trillion rupiah and various kinds of losses received, such as victims suffering from respiratory diseases, failure in transportation networks \& various activities, and threats to biodiversity.

With the existence of presidential regulation no 1 of 2016 and the establishment of the Peatland Restoration Agency as well as various regulations contained in the Ministry of Agriculture and the Ministry of Environment and Forestry that the use of peatlands has important roles for environmental management in Indonesia.

Changes in extreme weather conditions have caused various natural disasters in Indonesia. One of the ways to slow the pace of climate change is to protect peatland. Another solution that can be pursued and implemented is peat restoration, which consists of the stages of mapping peatlands, determining the types of actors and the timing of restoration implementation, rewetting peatland, replanting (revegetation), and involvement of local communities around peatlands.

One of the things that can be optimized is by providing education to the Community regarding the role of the peatland in reducing the rate of climate change and inviting the Community to be more concerned and willing to work together to protect the peatland. This education can be channeled through various activities such as writing, social media, creating community participation platforms, and capacity building training.

To address the reduction in peatlands in Indonesia due to forest burning, better regulation is needed. But for better regulation to be achieved, there needs to be public awareness first. Media is one way to increase public awareness. With the awareness of the Community, it is hoped that the encouragement to deal with the reduction in peatlands can be implemented. In addition, it is also useful to prevent the same thing from happening again in the long run.

The use of media is one of the tools to increase public awareness so that they are more aware of the importance of peatlands. The existence of a Sustainable Peatland System is also intended to increase the direct community contribution to inhibiting the 
reduction of peatlands. Even though public awareness is high, if the contribution is lacking, then public interest will decrease.

1.1. Background

Awareness is an important matter for realizing a problem. It is the basic step for thinking about a solution, taking action, and making an impact. The media has an important role to play in increasing public awareness and several levels of society so that they care and love peatland space. The types of audience that will be targeted are:

1. Absolutely don't know about peatland

2. Knows but doesn't care

3. Know but have no room to contribute

4. Know and can contribute but not effective

In order to achieve awareness among people, the content of media needs to be informative, simple, and give the key message towards targeted audiences. Regarding the peatland problems, people, especially millennials, as the key audience, need to know the importance of the peatlands and their critical conditions. To address problems and collaboratively searching solutions, strategy communications are needed. Understanding how people gain information is important.

Sharing the vision, goals, and objective openly is also an important thing in order to share the value of movement. Each person that is already aware can participate through sharing the knowledge in order to achieve sustainability awareness. Output and feedback play an important part in order to create out of the box solutions.

They realize the importance of people's awareness and participation. Therefore we aim to provide knowledge to all social strata to be able to care and contribute directly or indirectly and feel the results of their concern with results that are visible or can even be felt by participants who contribute directly. Millennials are the most targeted people segment and the ones that are expected to actively participate in the movement.

\subsection{Research Question}

The questions about this research include:

1. What are the strategies used to increase awareness of peatlands?

2. How can the Sustainable Peatland system be used as a tool to promote and increase awareness of peatlands?

\subsection{Purpose and Objective}

1. Knowing the strategies used to increase awareness of peatlands

2. Knowing how the Gambut Lestari is sustainable as a tool to promote and increase awareness of peatlands.

\section{Literature Review}

Public awareness about the environment is a stage of infancy. This is a very basic and important stage to protect and conserve the environment. Knowledge needs to be transferred effectively because incomplete knowledge will lead to a misconception or making people think the problem is not serious enough. Through comprehensive 
understanding, the knowledge and awareness about the environment will have an impact on the present and future (Vineet Kaul 2017, 686).

Media can be used for raising environmental awareness. Providing information through the media can be useful, especially to educate people about certain environmental issues. Another way to raise the environment through the media is by campaigning. To ensure the media can be an effective medium, the content creator needs to understand the context or background of the issue, identifying and targeting the audience, identifying the objective of the message, calling for action by inspiring the audience, choosing the activity to support the message, monitor and evaluate the effectiveness of the message. (Kloet and Morgan 2007,3)

Diffusion of Innovation Theory is explaining how and when an idea will spread and diffuse to certain communities. The result of this theory is people can adopt new ideas or a new behavior that is different from their previous act. The adoption of the idea and behavior needs to be started by innovation. People's decision to innovate can be influenced by individual decisions or authority decision. The individual decision started with awareness, then follow by interest, evaluation, trial, and adoptions. (Rogers 2003:317)

In order for the idea or innovation can be linked to society, there is a need for a change agent role. Alter operators create a require for altering, set up an information-exchange relationship, analyze issues, make expectations to alter in society, decipher the aim into activity, stabilize appropriation and anticipate discontinuances, achieve the change of behavior. The developed need for change roles is the role of a change agent to make society aware of the need to change their behavior or adopt new ideas, pointing out alternatives of the problems, emphasizing the importance of the problems, and ensuring them that they are capable of tackling this problem. Translates intent into action, by working together with certain parties, change agents influence the Community to make a change. (Rogers, 2003, 316). These two roles of change agents are the ones that we emphasized in Gambut Lestari.

Aspects of education, cultures, interests, opinion, and complex environmental circumstances will take place and can be contrast when an institution is trying to develop a campaign of awareness and do the communication. Anticipating all the circumstances and how the people will respond to the actions (positively, neutrally, or negatively) is really matter besides getting your message to the right target audiences. To be prepared, the institution must be equipped with few tools and consider some strategy such as:

\subsection{SWOT Analysis}

SWOT-analysis helps institutions determine where they are and what risks they will face when developing an awareness and communication strategy.

2.2 Awareness and communication Strategy (implementation)

Awareness and communication strategy development need goals that are measurable and specific in order for the message can be delivered effectively, and the activities can be performed well through the medium.

Based on WWF standard for project and Program Management, awareness and communication strategy can be implemented by:

1) Understanding the context and the background for implementing the awareness and communication strategy 
2) Identify the target audience

3) Identify the objectives

4) Identify the key message that will be communicated to the target audience dan call to action to inspire the target audience

5) Choosing the activity and tools for facilitating communication-related to key message and call to action

6) Monitoring and evaluating the message that wants to be delivered

2.3 Feedback, Evaluations, and Audits

A feedback mechanism is important, and it will influence the project life cycle. There are two important factors of feedback mechanism, which are project evaluation and audit. Project evaluation is assessed based on specific performance criteria. On the other hand, project audit is assessed based on external standards, for example, input from a form that is filled by external parties. Both project evaluation and project audit can be done in every phase of the project cycle. Internal evaluation can be done by internal teams. External evaluation can be done by third parties.

\section{Research Methods}

\subsection{Project Planning}

The arranging for the full extent is the strategy received for the venture as surrounded in figure 1.0. It includes a few stages of the guiding stage to be the center activity stage, which is the center of this paper. This paper highlights the outcome of the guided survey. This questionnaire may be a vital introductory stage because it will distinguish the investigation information hole between the analysts and the Community. It is additionally to decide the legitimacy and unwavering quality of the developments that had emerged through a dialog between the inquire about the group and the local Community. These discoveries will be the stage for analysts to require assist activity plans to realize the inquiry about results.

Figure 1. The project Planning Map
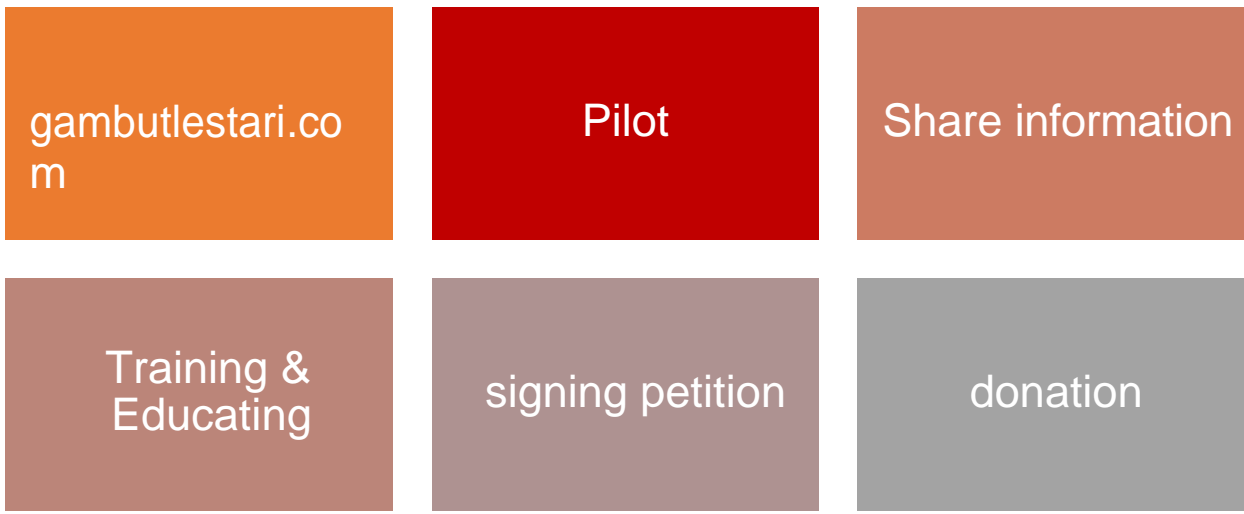

Source : Adapted from (Othman, 2015)

32. Data Collection Instrument

We referred to a sampled questionnaire survey from Institut Pertanian Bogor that surveyed Community Perceptions regarding peatland restorations regulation in 
Kalimantan Tengah. They used the parameter to know how much knowledge that Community has and their perceptions. Those parameters are: 1) Community's knowledge about peatlands restoration (P1) 2) Community's supports for peatland restoration (P2) 3) Community's willingness to cooperate for peatland restoration effort (P3) 4) Activity that proposed for peatland restoration activity (P4) 5) Willingness to make "desa peduli" (P5) 6) Respondent daily activities related to peatland (P6)

The data that is used for this paper is based on $\mathrm{P} 1$ and $\mathrm{P} 2$ parameters only.

3.3 Prototype making

During Gambut Lestari prototype development, our team used a couple of processes, which consist of wireframe, identifying UI/UX, and prototype making that used Figma applications.

\section{Results and Discussions}

The Results and Discussions describe the field findings and analysis of the discussion.

\subsection{SWOT Analysis}

Situation:

Peatland areas are decreasing from the perspective of conservation, and this is a huge problem because the reason behind the decreasing area of peatland is because peatland is burned down by people for opening the land related to business purposes. There are also peatlands that are illegally acquired by companies. For communication purposes, there will be a lot of opportunities for communication. Through communication, there will be a lot of opportunities for us to educate the Community around the peatland related to restoration and further damage prevention.

Based on the findings, the SWOT analysis for Gambut Lestari are:

Table. 1 Strengths Weaknesses, Opportunities, and Threats Analysis

\begin{tabular}{|c|c|}
\hline Strengths (Internal) & Weaknesses (Internal) \\
\hline $\begin{array}{l}\text { - } \text { Some related information already } \\
\text { available in pantaugambut.id } \\
-\quad \text { International recognition and } \\
\text { respect for knowledge in peatland issue } \\
\text { already achieved } \\
-\quad \text { Access to an international network }\end{array}$ & $\begin{array}{l}\text { - In Indonesia, not so many people } \\
\text { know about peatland and its problem } \\
-\quad \text { Knowledge mission on social and } \\
\text { economic developments/aspects. }\end{array}$ \\
\hline Opportunities (External) & Threats (External) \\
\hline $\begin{array}{l}\text { - Society can help the peatland } \\
\text { restoration through fundraising and } \\
\text { donation } \\
\text { - Strong network government, } \\
\text { NGOs, and research institutes in place. }\end{array}$ & $\begin{array}{l}\text { - Illegal forest burning for the } \\
\text { purpose } \\
\text { - Low education level in } \\
\text { stakeholders' communities }\end{array}$ \\
\hline
\end{tabular}

Source: SWOT Analysis adapted from (Kloet and Morgan 2007,5) 
From the matrix above, the project team can conclude that this has received recognition from the International Community. On the one hand, there is a problem in the knowledge of the general public, especially those who do not live in peatland areas. However, there is an important opportunity in that society are noticing that their strengths are expanding. Despite the challenges to make them aware of the problem and to encourage them to give the donation, this campaign provides a good basis to communicate with the target audience.

It is obvious that the Gambut Lestari project must address its deficiencies in terms of socio-economic knowledge and internal communications before proceeding. Communication activities will only be effective if these issues are addressed first. This has implications for the awareness and communications strategies and perhaps also the team members.

\section{Awareness of Communication Strategy}

\subsubsection{Communication Goal}

- Increase awareness of peatlands

- $\quad$ Raising concern but also encouraging the Community to be able to act directly in order to feel the struggle to protect peatlands

- In the long term:

- Linking the policies at a national level to support sustainable activities for peatlands

- Achieving Community based natural resource management (Allowing and supporting the Community around the peatlands to have control over the management of peatland and it is resources to gain a sustainable environment)

Table. 2 SMART Analysis

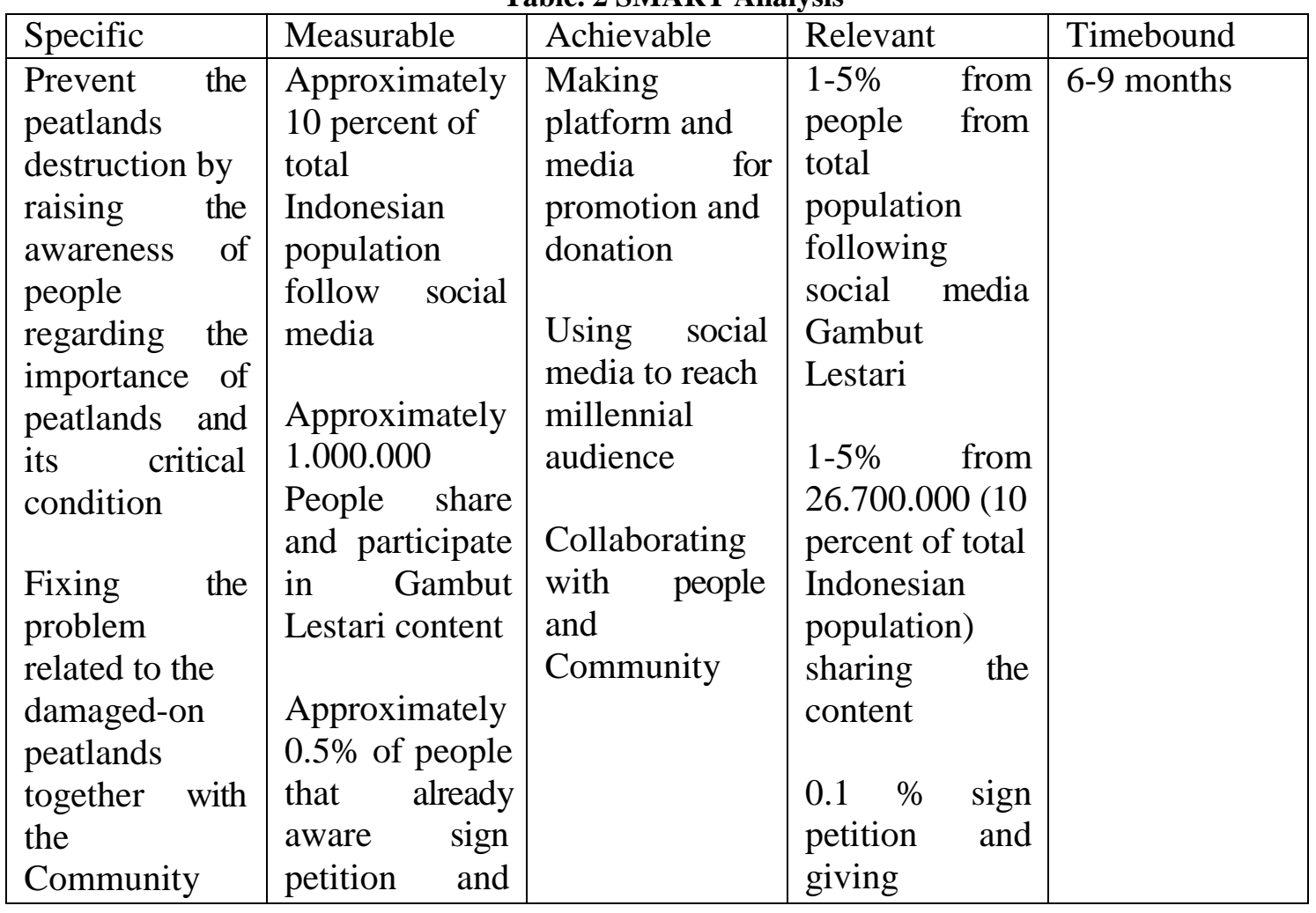


and people in general

\section{giving}

donation donation

Source: Adapted SMART analysis (in WWF 2012, 22-23)

\subsubsection{Audience}

Figure. 2 Audience Percentage Data

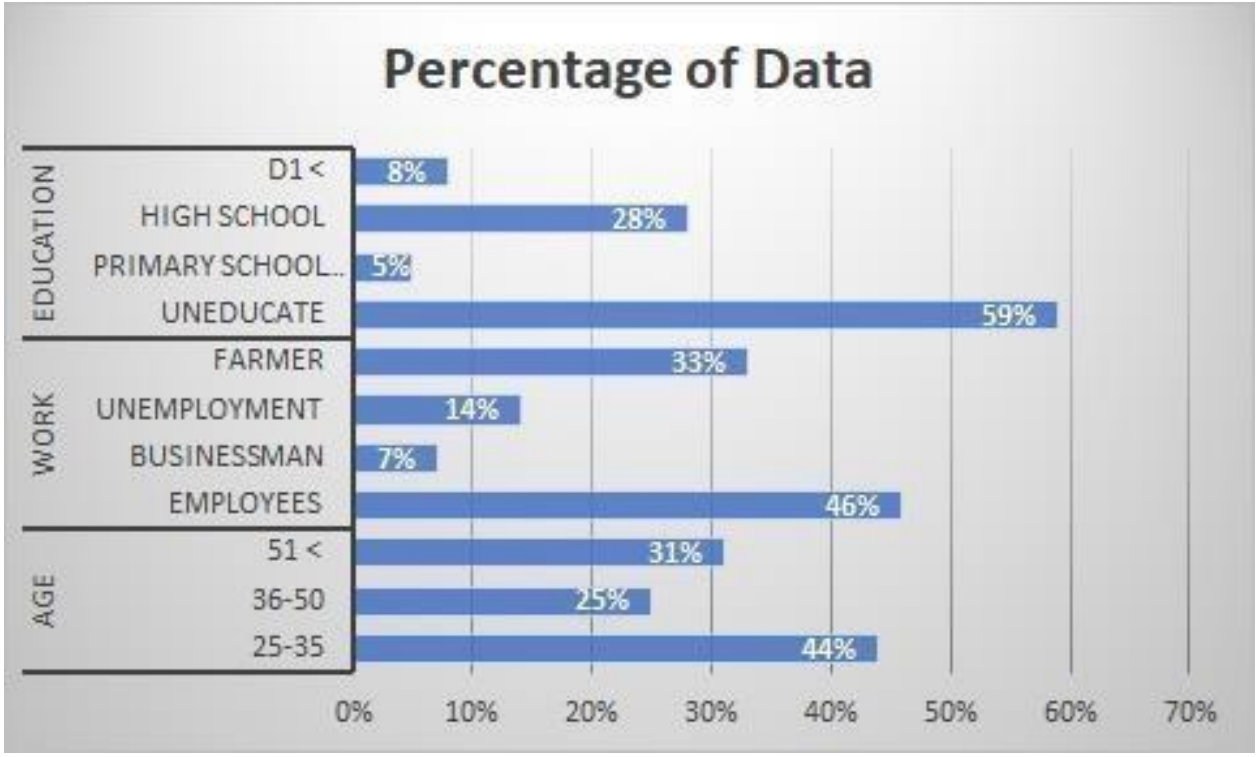

Source: Respondent identity composition (in Rhamdan 2017, 69)

The general condition of the respondent's identity, age distribution, education level, and occupation are shown in the Figure above. In terms of age, the majority of respondents are of productive age, namely 36-50 years, with a total of 38 out of 86 respondents. For the level of education, people who were interviewed the most only at the primary education level first (SD, SMP) as many as 51 people. As for daily livelihoods, many respondents work as employees $46 \%$ and farming $33 \%$.

Figure. 3 Percentage of Awareness

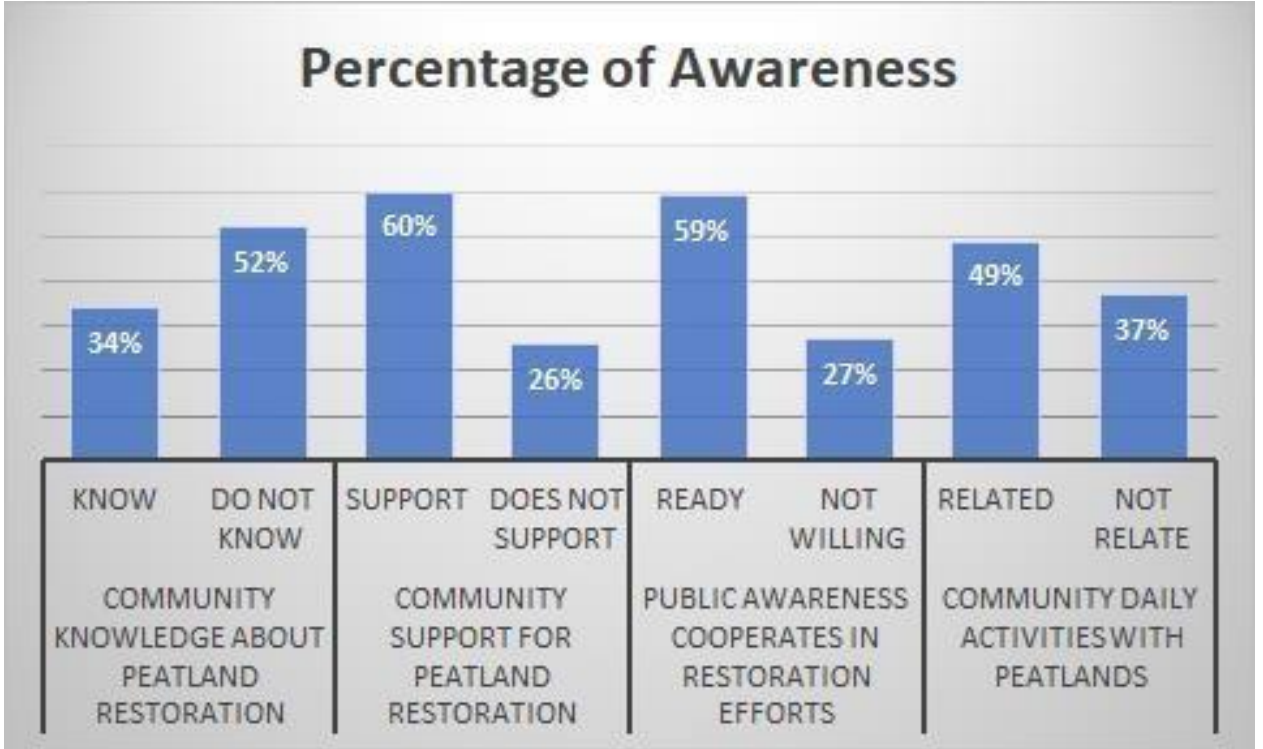

Source: Graph of questionnaire results regarding community perceptions regarding peatland restoration in Central Kalimantan province (in Rhamdan 2017, 69) 
In fact, there are still many people who do not know about the peatland restoration plan initiated by the government; as many as 52 people answered no to P1. This shows that the socialization of the peatland restoration program still needs to be improved. Although more people do not know, the Community answered that they support this program in P2; 60 people expressed their support for peatland restoration. More people are also willing to cooperate with the government in implementing peat restoration programs.

Figure. 4 The amount of time that millennials spend on internet consumption

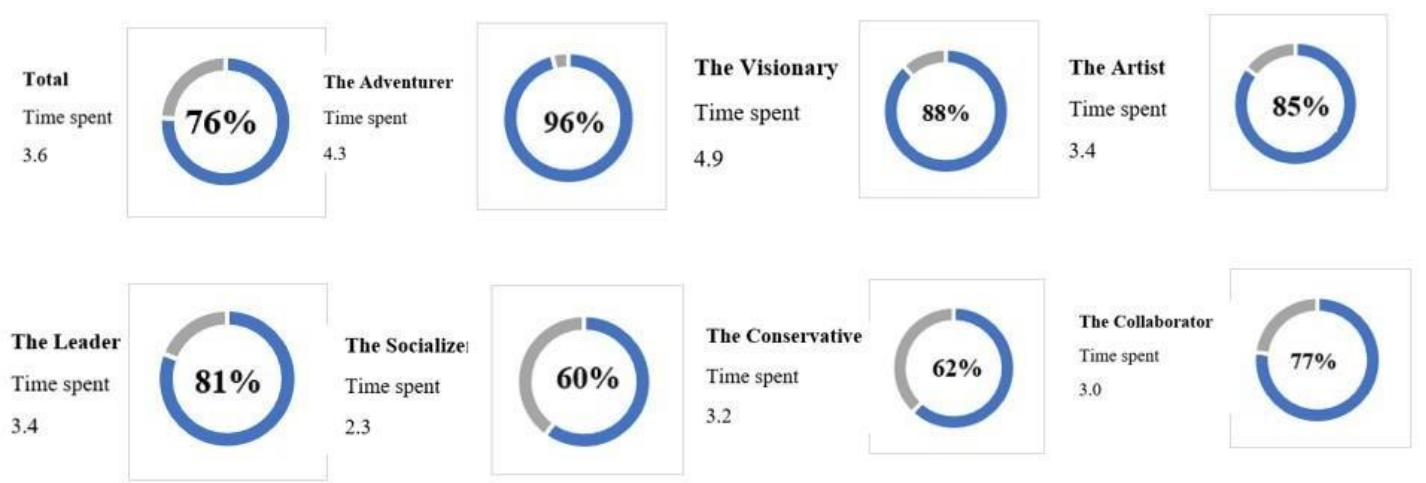

Source: Indonesia Millennial Report 2020 (in IDN Research Institute 2020, 77)

\subsubsection{Key Message and Call to Action}

After choosing the target audience and objective for communication strategy and awareness, the information will be delivered. It is related to what kind of information will be delivered, how it will be delivered, how it can increase the knowledge of the target audience, influence their behavior, and have an impact on their behavior.

Key messages need to have an important point and benefit to the target audience in order to make their behavior effectively change. The key message that we use in this project are:

"Burning down peatlands will affect the environment, Community, and economy negatively. By being a part of the actions to stop those conditions, you will protect the Community's environment, global environment related to climate change, and economics."

Therefor public will change their behavior because:

- It can save the environment, economy, and the future

- It can prevent peatland damage in the future

- It can fix peatland damage that already been done

- This is a platform to share generosity towards each other.

Calls to action that will be done are signing the petition and giving donations. In Gambut Lestari, people can help the peatland damage prevention and restoration by giving donations with only 500 rupiahs.

\subsubsection{Communication Tool}


Creating an application that can help achieve predetermined goals to make it easier to achieve predetermined targets, and with this, we provide an idea to be able to create an application that is "PUSH-GAMBUTLESTARI."

There are some requirements which are very simple on this mobile application consist of:

1. Email Registration.

2. A petition to support peatlands with existing terms and conditions in the form of information that you have agreed to always support the protection of peatlands from irresponsible parties.

3. Make one button:

A. pressing the button for the first one means agreeing with the movement and the petition.

B. Pressing the button for the second time means wanting to support and donate "Rp. 500.00" to local community economic development, hire a lawyer so that you can fight for the peatlands that have problems throughout Indonesia.

4. Information will be given so that you can transfer to the bank to be able to donate in pop-up form.

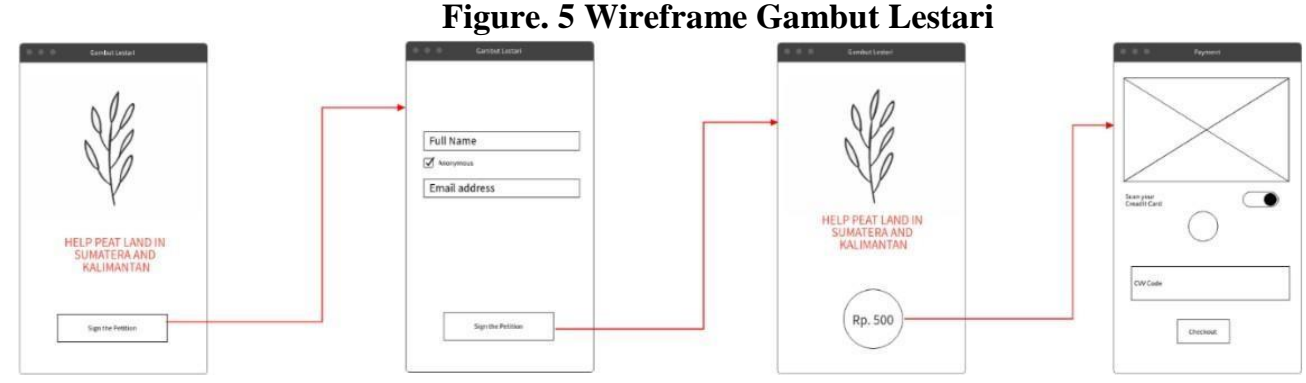

Source: Author's Analysis Results (2020)

Figure. 6 How to Donate in the Application

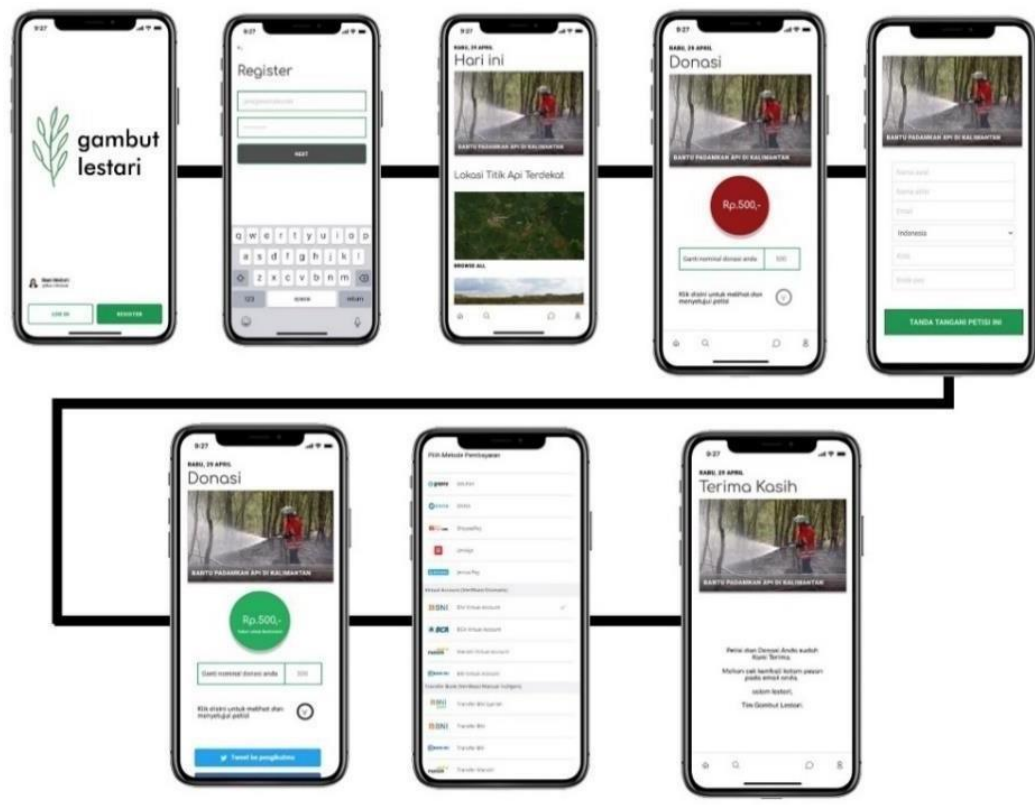

Source: Author's Analysis Results (20 
Figure. 7 The connection in the Application

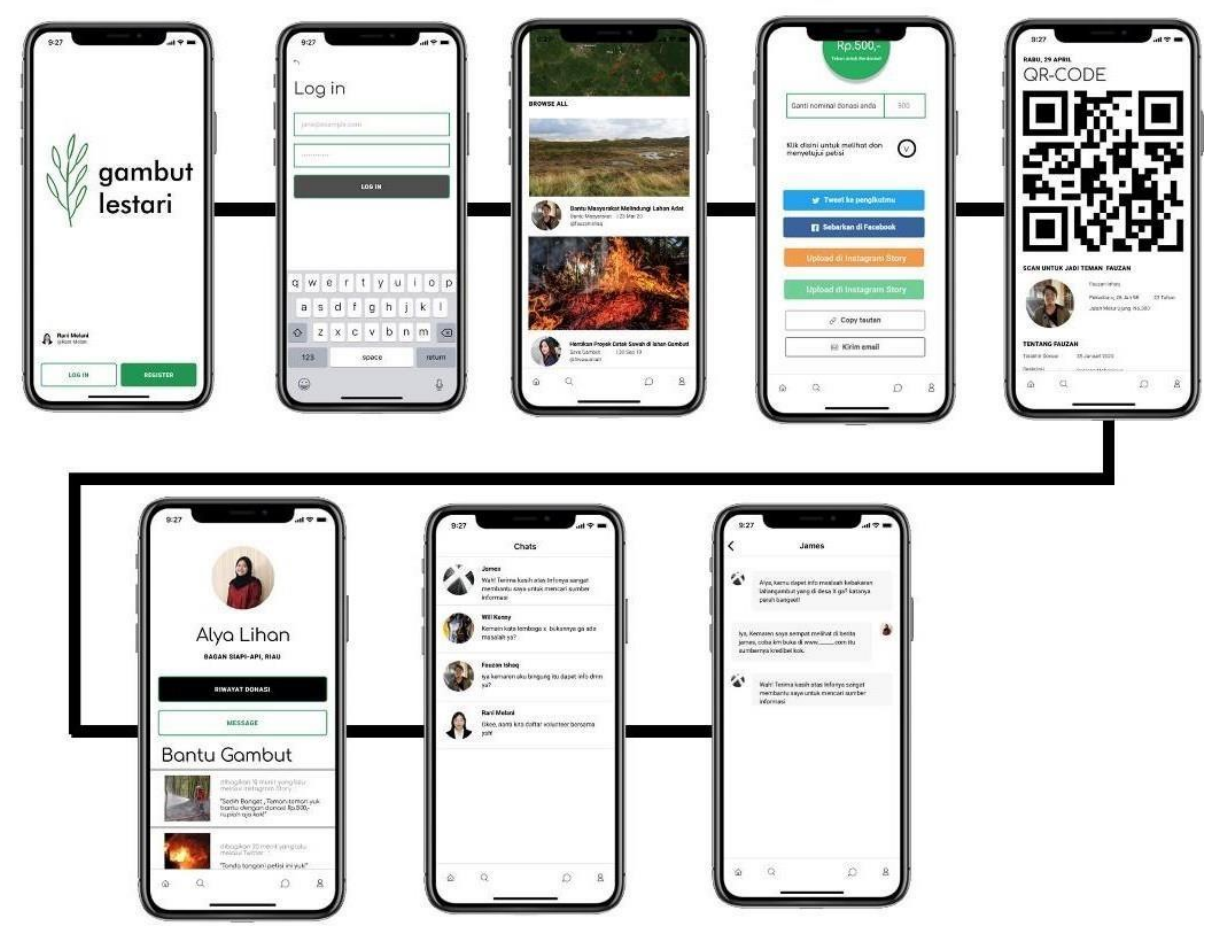

Source: Author's Analysis Results (2020)

\section{Stakeholder}

Targeted stakeholder:

- $\quad$ NGO: As channeling agency for donations and helping to assist strategies to increase awareness of Gambut Lestari

- $\quad$ Pantau Gambut: The raised funds will be donated to Pantau Gambut for restoration

- Lawyer: Handling dispute regarding peatlands as a representative of the Community.

- $\quad$ Another Organization relates to peatland or protection of biological resources such as WWF Indonesia and Forest Watch Indonesia.

4.4 Strategic Activity

- $\quad$ Understanding and targeting the audience

Understanding the attitude, demographic, lifestyle, awareness, and how to make people involved in the action. In the millennial era, the tools that can be used for mass communication are a social network, online video, websites. Those are the ones that are utilized regularly. However, there are some chances for offline media that are still publicly liked, such as Radio and Television. Even though every person is different, they can be classified as the adventurer, the visionary, the artist, the leader, the socializer, the conservative, and the collaborator. Each group has its own tendencies and preference to gain information. 
- Partnership with other parties in order to gain the right information, accessibility, get a greater impact.

A successful campaign depends on how effective the collaboration, along with the key stakeholders. A conservation project may, Therefore, in order to ensure everything can be carried out, it is necessary to have effective cooperation and share information with the stakeholders during the project, even after the project ends.

Using the media to gain awareness (Giving the key message to the audience, delivering the issue, statistic, and principle)

Raising environmental awareness can be done by using the media. One of the media that can be used is a mailing list, Facebook, Twitter, Instagram, YouTube campaigns that inform current conditions and future events. Other than that, offline media that can be used, such as radio, television, and magazine.

- Call to action encouraging the audience to participate, for example, signing a petition, donate, etc.

The society that is already interested in the campaign through platforms will help the problem related to peatland. Therefore, they need to be facilitated for doing their activities such as donating or sharing information. This will have a domino effect on the campaign.

- $\quad$ Fund Allocation

In this stage, the donation that already collected will be allocated to the campaigns that are available in the Application. In other words, the fund will be allocated based on the campaign event that every donor chooses and cares for.

\subsection{Feedback, Evaluations, and Audits}

In order to determine the project's effectiveness and adaptability, teams need feedback about the strategy and result. The feedback and the process to resolve it can be a good input. Even though the feedback from some organizations can be limited only for reviewing the performance in a formal way, informal feedback about application design and user experience related to the Application that came from colleagues and friends will be a good source to increase the project performance. Informal feedback can be done with a direct meeting, email, phone call, or filling the feedback form. Feedback will be a twoway process, which after the customer gives the feedback, their feedback will be resolved and get a reply. In the prototype, we use google form for getting the feedback.

\section{Conclusions and Recommendations}

Peatland is a natural resource that has a lot of potentials and can absorb carbon. The function of peatland for absorbing carbon will affect the world, to be specific, related to climate change, however, because the function of peatland has already changed by people, which are for palm oil plantation, etc. Moreover, the way people open the land for business purposes is not environmentally friendly, which is by drying and burning the peatland. The unique thing about peatland that burned down is the fire will spread under the ground and not visible on the upper ground; only the smoke will be visible. The smoke also will cause a disadvantage for the environment and Community too. 
In order to put an end to these disadvantageous situations, the awareness of people needs to be raised. One of the ways that will improve public awareness is through the media. By increasing people's awareness, it can prevent peatland damage and indirectly fix previous damage that has already been done. With Gambut Lestari application, a pilot project specially made for raising awareness about peatland and a platform for facilitating people's action related to peatland issues through donation; hopefully, restoration, land dispute, or other agrarian conflict related to peatland issues will be resolved. The mechanism used in this Application is "one-click for donation and sharing the information through social media." 


\section{BIBLIOGRAPHY}

\section{Book}

Presidential Regulation No. 1 of 2016. Jakarta. 2016.

Rogers, Everett M. 2003. Diffusion of innovations. New York: Free Press.

\section{Journal}

Othman, Zarina., Ishak, Anizan., Mokhtar, Mazlin., Elfithri, Rahmah., Toriman, Ekhwan., Mohamad, Wan Nue'ashiqin W., Ya'acob, Azizah., Latiff, R. Abdul. 2015. Communication environmental awareness: Water information and its discourse. Accessed on 16 October 2020 via Research gate.

Vineet, Kaul. 2017. Environmental crisis and the role of the media.International Journal of trend in scientific research and development volume 1(4): page 686.

\section{Website}

IDN Research Institute and Nielsen holdings plc. 2020. Indonesia millennial report 2020. https://cdn.idntimes.com/content-documents/Indonesia-millennialreport-2020-by-IDN-Research-Institute.pdf. Accessed on 16 October 2020.

Kloet, Anne-Marie, WWF NL., Morgan, Alexis, WWF Canada. 2007. Conservative strategies: Awareness and Communication March 2007, Resources for implementing the WWF Project and program standard. World Wildlife Fund (WWF). Accessed on 10 October 2020.

Pay, Pardi. 2017. Gambut?. Forest Watch Indonesia (FWI).

https://fwi.or.id/publikasi/peran-penting-gambut-dalam-mengurangi-lajuperubahan-iklim/ . Accessed on 16 October 2020.

Ramdhan, Muhammad. 2017. Analisis persepsi masyarakat terhadap kebijakan restorasi lahan gambut di Kalimantan tengah.Risalah Kebijakan Pertanian dan Lingkungan Vol. 4 No.1, April 2017 : 60-72. https://doi.org/10.29244/jkebijakan.v4i1.20066. Accessed on 22 October 2020.

World Wildlife Fund (WWF). 2012. Standards of conservation project and programme management (PPMS).

https://wwf.panda.org/organization/programme_standards/. Accessed on 21

Oktober 2020. 